\title{
Migrant Remittance and Household Expenditure Pattern in Nigeria
}

\author{
Adenike Adeseye \\ National School of Political and Administrative Studies SNSPA, Bucharest, Romania \\ Email: adenikeseye@gmail.com
}

How to cite this paper: Adeseye, A. (2020). Migrant Remittance and Household Expenditure Pattern in Nigeria. Open Journal of Political Science, 10, 73-98. https://doi.org/10.4236/ojps.2021.111006

Received: November 15, 2020

Accepted: January 15, 2021

Published: January 18, 2021

Copyright ( 2020 by author(s) and Scientific Research Publishing Inc. This work is licensed under the Creative Commons Attribution International License (CC BY 4.0).

http://creativecommons.org/licenses/by/4.0/

\begin{abstract}
This research work examined migrants' remittance and household expenditure pattern in Nigeria. The study adopted survey research method. The quantitative study was utilized with the aid of questionnaire. The respondents were selected using convenient and random sampling techniques. Two hundred copies of questionnaires were administered on migrant households in the study area while one hundred and sixty-six questionnaires were returned. The data collected were analyzed through descriptive statistics, such as frequency tabulation and simple percentage compilation; hypotheses formulated were tested with the use of chi-square statistics. From the findings of the study and the tested hypotheses, it was discovered that there is a significant relationship among remittance, income, consumption expenditure and investments of households in Nigeria. The study therefore proffers some recommendations towards utilizing influx of remittance for households' expenditure in Nigeria.
\end{abstract}

\section{Keywords}

Remittance, Expenditure, Migrant's, Investment and Income

\section{Introduction}

For a very longtime, individuals have been on the move looking for economic opportunity. In the twentieth century, technology advances and undiscovered natural resources drove developments of population from all around the globe. Global migration produced tremendous upgrades in individuals' lives. Immigrants delighted in higher wages, destination countries benefitted from expanded flexibly of work, and migrant homeland labor market pressures ease. Recent trends demonstrate that pressures for migration from the south toward the north are set to increase once more. This development is obsessed by pay 
holes and the rising number of youthful grown-ups in developing nations looking for better breakthrough abroad. The monetary, social, and political ramifications that accompany the development of individuals vary from the movement of goods or cash. Subsequently, the subject of global migration has incited a lot of political discussion in the global network today. Today, around 260 million individuals live temporarily or permanently in remote nations around the world, especially in the modern countries. Over the past decades, their number has almost multiplied (OECD, 2017).

There are numerous elements related with human migration. Lee (1966) characterized the fundamental variables which motivate migration as Push-Pull Factors. The push factors are elements that make an individual, due to numerous issues, to leave his homeland and move to some other location. The normal push factors are low success, joblessness and underdevelopment, poor monetary conditions, absence of chances for progression and common cataclysms. The non-accessibility of different sources of revenue in rural space is similarly substantial element for migration. The Pull Factors are elements that draw in the migrants to a particular zone. Opportunities for worthy business, good wages, better working conditions and pleasing facilities are pull basics to a region (Lee, 1966; Kyaing, 2012).

In regards to movement outside Nigeria, there has been an astounding increment in emigration to Europe, the Middle East, North America, and South Africa from 1980's after monetary downturn, arrival of liberation measures and rise of harsh military autocracy. A large number of experts, particularly researchers, scholars, and those in the clinical fields have emigrated, for the most part to Europe, the United States and Persian Gulf States. Simultaneously, unskilled individuals from Nigerian with little education have traveled to another country to fill in as road cleaners, security watches, cab drivers, and manufacturing plant hands. Migration is viewed as basic to making progress. These migrants frequently dispatched or transferred substantial part of their expanded profit to families and friends back home. At the same time, remittances have become important private financial related assets for family units in homeland of migration in spite of the fact that they can't be deliberated as alternative for foreign direct investment, official advancement aid and poverty alleviation (Anyanwu \& Erhijakpor, 2010).

Remittances remain significant and constant avenues of private inflows to emerging nations, as they provide substantial amounts of overseas cash that support and tolerate the balance of payments. Remittances diminish the poverty and lead to increase human capital accumulation; improve wellbeing; improve access to finance related areas; lead to more business enterprises; and better readiness for negative shocks. Remittances provide significant avenue of foreign exchange, capital, innovation, and information for nations of starting point and destination. Returning migrants take home the skills they acquired and before that, normally have transferred funds to their homeland. Remittances add to monetary development and to the employments of numerous individuals origi- 
nating from less fortunate locales around the world. Additionally, remittances sent can likewise elevate access to economic administrations for the sender and beneficiary, thereby supporting investments and expanding money related and social inclusion.

As per the World Bank, in 2019 worldwide remittance arrived at a record USD 554 billion in 2019 expanded up by 4.7\% weighed with 2018, surpassing Foreign Direct Investments (World Bank, 2020), the main five settlement beneficiary nations were India ( $\$ 83.1$ billion), China ( $\$ 68.4$ billion), Mexico ( $\$ 38.5$ billion), the Philippines ( $\$ 35.2$ billion), and the Arab Republic of Egypt ( $\$ 26.8$ billion) (World Bank, 2020). In comparative terms, the main 5 nations which got the most noteworthy remittance as a portion of total national output (GDP) in 2019 were: Tonga (37.6\% of GDP), Haiti (37.1\%), South Sudan (34.1\%), the Kyrgyz Republic (29.2\%), and Tajikistan (28.2\%) (World Bank, 2020). Moreover, the amount of informally dispatched cash could be a few times higher. This can be considered as an extraordinary commitment to household economies, critics contend that this cash is fundamentally influencing consumption, instead of adding to longer-term sustainable development and advancement. Migrant transferred of goods or cash has become a momentous basis of revenue and foreign exchange for emerging nations. A large number of family units are influenced by migration through cash or goods transferred to the migrants' homeland. Global remittances comprise the second biggest avenue of net capital inflows after foreign direct investment which surpasses foreign aid. It is evaluated that inflows of migrant remittances to emerging nations currently exceed official advancement aid in many emerging nations (World Bank, 2018).

Nigeria's remittance inflows continue to be among the most noteworthy in Africa with high commonness of familiarity. Remittance inflows into Nigeria are by a wide margin is one of the most significant in Africa. In 2017, they were the 6th most elevated on the world. In 2018, USD 24.2 billion was transmitted to Nigeria a 9\% growth rate from 2017. The Central Bank of Nigeria (CBN) credits this development to improved economic conditions of the world (CBN, 2017). These noteworthy flows establish one third of official flow of remittance into Africa and are ten times greater than Senegal, which is the second most elevated beneficiary in SSA. Remittances were valued as $5.9 \%$ of the Nigerian GDP in 2017. This is a great figure given that Nigeria is Africa's biggest economy. Capital and remittance flows have increased rapidly since 2005 because of the introduction of the Nigerian capital market, and the nation is considered to have linked with the positions of frontier markets (IMF, 2016). Different sources exposed that the flows are comprehensibly undervalued, in such case, with as much as half of remittances inflow to the nation through unofficial sources are not caught in the official information. Transferred remittance remained at about USD275 million of every 2017, making Nigeria a significant beneficiary of remittances.

In the migration literature, there are immediate and indirect impacts of re- 
mittances on expenditure of nation's economy. Remittance can be seen as monetary inflow emerging from the movement of people, and the disposal of cash and items by migrants to their homeland. Household expenditure is the amount of final consumption and spending made by families to meet their daily needs such as food, furniture, accommodation, vitality, transport, vehicles, wellbeing costs, recreation, and different administrations. The impact of remittance inflow on recipient families varied (Waheed et al., 2013). In the widest sense, there are positive and negative views on the effects of receiving remittances and speculations have swung between the two. On the constructive side, the immediate impact results when the remittances are coordinated towards investment costs and many policy makers hope that the money received through remittances will be invested to guarantee the basic needs of families, working towards development of the economy, or add to individual savings. On the adverse side, opposing discoveries have recommended that remittance cash, on several instances, is not used for long-term investments, but rather allows obvious consumption or has a limited impact on investments, while indirect impact results when it is coordinated towards family income, education, health care costs and poverty reduction. Above all, families who receive remittances likely to spend more on consumption, wellbeing and education (Adams, 2011). Therefore, this study seek to examine migrants' remittance and expenditure pattern of households in Nigeria.

The study seeks to examine migrants' remittance and expenditure pattern of households in Nigeria. The study addresses the below objectives of the study are thus:

1) Ascertain the extent at which migrants remittance influences households income level in Nigeria;

2) Find out the extent at which migrants remittance influences households spending pattern in Nigeria;

3) Investigate the extent at which remittance influences households investment decisions in Nigeria.

\section{Statement of Problem}

The rise of geographical labor mobility due to economic hardship, redundancy and insecure monetary conditions, among other factors, particularly among experts, has been related with brain drain in African nations. In any case, migration is not generally favorable. Labor migration around world presents obvious difficulties, employees and managers worried about the rights of all workers in their supply and workforce, including migrant workers. Migrant workers are progressively helpless against infringement of their principal rights, exploitation and abuse, segregation and unequal treatment and freedom of association. Employers of migrant workers may face legal impediments in respect of the rights of migrant workers; For instance, in many countries foreign workers are restricted by law from joining a union. At the same time, there are a lot of chances for organizations and employers to have a positive influence on the extensive 
debate on global migration and to coordinate migrant workers into their various tasks or working environments in a human, reasonable, efficient and genuinely increase the value of social orders and organizations (World Bank, 2015).

Remittance flows, which are an indispensable piece of improvement finance, demonstrated moderately strong during the 2008 financial crisis and the 2014 Ebola pandemic. Nevertheless the world as of now is under danger by the COVID-19 pandemic. Remittance flows in 2020 to low and middle income nations are anticipated to drop by $19.7 \%$ to USD 445 billion, perhaps the worst decrease in the history (World Bank, 2020). As indicated by the World Bank, this fall is to a great extent because of the financial emergency brought about by the COVID-19 plague; for migrant laborers, the pandemic has implied a fall in earnings and business. Lockdown estimates actualized in host nations have made numerous migrants lose their jobs, subsequently decreasing remittance flows to emerging nations. In 2020, the World Bank evaluates a decrease in worldwide remittance of US $\$ 110$ billion, with sub-Saharan Africa (SSA) expected to encounter a decay of about $23.1 \%$. People, families, organizations and countries that are exceptionally reliant on remittance flow are as of now enduring an immense finance related upset (World Bank, 2020). The estimated increased fall in remittance will subvert building up nations' capacity to manage the COVID-19 pandemic, not to mention their capacity to accomplish the Sustainable Development Goals (Amanda, 2020).

It is imperative to stipulate that despite the position of Nigeria as top remittance beneficiary nation in Africa and fifth on the world in 2013 budgetary year, the Central Bank of Nigeria is uncertain about the genuine measure of monies transferred to the nation because of its absence of strategies to quantify casual routes through which remittance move to the nation. This proposes remittance enter the nation through informal ways and this could be make the official figures not exactly precise impression of the truth as individuals like to send remittance home cheaply requiring little to no effort, for the most part through friends who is visiting their homeland. It is essential that Nigerians overseas were recorded to have transmitted US $\$ 10 / \$ 21$ billion out of 2010 and $2013 \mathrm{fi}$ nancial year separately, and this placed the nation in front of other African nations as the most remittance beneficiary nation. In spite of the high flow of remittance into Nigeria, hardship and inequality are still rampant in Nigeria, and the nation is unable to utilize remittance like other developing nations, for example, Philippines and Mexico (Adams, 2011).

\section{Theoretical Framework}

There is no single theory can fully explain migration, remittance and household expenditure given the fact that their drivers are complex and multifaceted. There are a number of theories that can be relied upon to explain the drivers of remittance and household expenditure, hence, Dual Labour Market Theory, Implicit family contract theory and Theory of migrant network provide theoretical basis 
for proper understanding of the study. Below are the hypotheses to be evaluated for review.

* Migrant remittances and income level of households Crosstabulation

* Migrant remittances and expenditure pattern of households Crosstabulation

* Migrant remittances and investment decisions of households Crosstabulation

\subsection{Dual Labour Market Theory}

The dual labor market theory, also known as segmented labor market theory, stressed that migration is reaction of the labor market pressure of the advanced nations (Piore, 1969; Piore, 1970; Doeringer \& Piore, 1971). The dual labor market theory holds that the request for low-level workers in the more advanced economies is the critical factor that forms global migration. According to this theory, migration is brought from fascinating (pull) elements in industrialized territories and not by pressure (push) elements in sending nations. It is the economic structure of advanced nations that requires a permanent job offer. The dual theory of the labor market has underlined that the market can be described by the presence of two distinctive sectors, namely the primary and secondary segments. The representatives of the first sector enjoy stable employment, great working conditions and high advancement prospects. The primary sector contains privileged members of the workforce. It represented an internal job market. Relatively high wages are paid; there is stable work with good working conditions and job safety. This theory was mainly used to clarify how circumstances in receiving nations draw migrants around the world and restricting their job prospects after arrival. Therefore, global migration is considered from the point of interesting (pull) elements in developed nations, in particular aspects essential in their labor markets rather than driving (push) elements in sending countries (Massey et al., 1993).

In a dual labor market, a secondary sector is categorized by short-term business opportunities, next to zero possibility of internal promotion. In terms of professions, they are mainly low or inexperienced jobs. The secondary sector is made up of works without expertise particularity. Employment in the secondary sector makes or strengthens bad work habits, such as unstable work arrangements, low level of promptness and absentmindedness. Wages in these engagements are low. This area has poor working conditions, gives little or no professional prospects and barely any advancement possibilities. Presumably, migrants in this category earn relatively low. Therefore, we can contend that secondary division is an essential feature of emerging nations that inspires migration. This huge informal segment constructs a persistent source of laborers prepared to find employment elsewhere, just on the request for secondary sector workers in established industrialized nations such as the countries of Europe makes consistent interest for immigrant laborers (Piore, 1975).

Therefore, migration may along these lines be viewed from the consequence of labor market situations inalienable to emerging nations as opposed to indi- 
vidual or family factor, despite the fact that the impact of these market situations can be explained through individual and family decisions. It is recognized that migrants who work in primary segment are probably going to transfer remittance to their homeland. It is frequently contended that the migrants in primary class are prone to increase economic well-being of family at home, gratitude to a moderately higher flow of remittance. These migrants typically earn relatively more and, will subsequently remit more. Conversely, they are also expected to spend a longer span of time abroad and furthermore are bound to rejoin with their close family in the host nation.

\subsection{Implicit Family Contract Theory}

This theory distinguishes family as the main unit of investigation (Stark \& Lucas, 1985; 1988). In this view family go into implicit agreements with individuals who migrate. These certain agreement includes investment and repayment assurance among household and migrants, and often lasted for a long while or decades. The understood agreement involve time-based dimension for different years or even decades. In the loan repayment theory, the household puts resources into the education of the migrant and generally funds the migration expenses and accommodation in the receiving nation. This represents the loan component of the hypothesis. The repayment takes place after the migrant settles abroad, his earnings begin to rise over the long run and he is in a situation to begin reimbursing the loan back to the family as in form of remittance. In this way the family puts resources into a higher yielding resource, the migrant who gains a higher salary in an outside nation than other relatives living and working at home. This theory predicts different time profiles of remittance, varying, among others, on the period of time it takes for the migrant to settle in the foreign labor market and on the span of his stay abroad. The sooner the migrant's coordinate into the labor market of the new nation the quicker the progression of remittance. The sums to be moved will depend, in addition to other things, on the earning profile of the migrant (Stark \& Lucas, 1985).

Another variation of this hypothesis as an implicit family contract between the migrant and families at homeland is based on the concept of risk diversification. The notion is basic as insurance and capital markets in reality are inadequate, and risks cannot be expanded in view of the lack of financial resources that edge risks. Furthermore, debt constraints, a particularly serious problem for poor migrants, limit the ability to regulate consumption or finance investments. Assuming that the economic risks between the host country and country of origin are not significantly related, at that point it turns into an advantageous procedure for the family to send a portion of its individuals abroad to diversify economic risk. The migrant, at that point, can assist with supporting his family in awful occasions at home. On the other hand, for the migrants, having a family in the homeland is insurance against the unpleasant occasions that may likewise happen in the host nations. In this perspectives, emigration turns into a co-insurance 
strategy, with remittances playing the character of an insurance claim. As with any contract, there is a potential execution problem (e.g. ensuring that all parties comply with the terms of the contract). Nonetheless, on a fundamental level, implementation can be relied upon to be less difficult because of the way that these are implicit family contracts which are aided by family trust and selflessness, an element regularly missing in legitimately authorized agreement (Stark \& Lucas, 1988).

\subsection{Theory of Migrant Network}

The network theory was proposed by Massey et al., 1987; Massey, 1988, 1989, which stressed that transmission of the migration experience from migrants to family members and companions in their homeland as an engine of global migration. Arango (2000) defined the migration network as a relatively steady relationship over time of beneficiary nations with migrants' homeland. As per Massey et al. (1993), migrations produce networks which at that same point feed the migration that created them. In this way, whatsoever micro social, cultural political and monetary circumstances that primarily caused migration originated from pushes and pulls factors, the growing migration procedure turns out to be logically independent to the real causal situations. Basically, migrations in process ascend over the conditions that made them, driving from that point of a liberated presence. Massey (1988) describes migratory networks as sets of relational bonds that connect migrants, ex-migrants, and non-migrants in homeland and host territories from the ties of kinfolk, friendship and common network of origin.

Networks stimulate autonomy of migratory flows for two reasons. Firstly, when network associations arrive at some limit level, they become self-governing social structure that underpins immigration. This emerges from decreased social, monetary, and emotional expenses of immigration allowed by the networks. In other words, the migrants supported by the network have significant impact in financing transportation, securing accommodation and work in the host territories, and in achieving a reasonable individual and emotive adaptation to what is frequently a hard condition of ethnic peculiarity. These advantages make migration simpler, therefore reassuring individuals to move rather than remained at homeland. Except if migrants are relocated, displaced people with no other option on leaving, while immigration gives them courage of subsistence. Given that decision, the diminished expenses of migration expands the amount of people who will choose to leave, therefore expanding the size of migration (Bozorgmehr \& Sabagh, 1990).

Secondly, Massey (1988) has put forth a similar defense for networks from the presumptions of risk diversification model. On this view, families designate labour to members within the limits of their needs and aspirations in a convenient way to minimizing risks. Several Third World families are risky economically. Such family units face high-dangers to their prosperity if they don't decide on 
migration. Besides, modernization and advancement make social and economic dislocations strengthen the insecure and unpredictable financial condition made by the dangers of drought and cataclysmic events, for provincial and urban territories. Without different approaches to safeguard against such dangers, expansion of household members limits the overall risk of family revenue (Massey, 1989). Global migration is particularly compelling in light of the fact that international borders make gaps between freedom of income at home and foreign territories. Great occasions in foreign territories can coordinate awful situations at home, or the other way around. Indeed, even without disparities of income, global migration creates a powerful risk diversification strategy, particularly when network of migrant previously exist. Migration networks diminish the economic threats of migration therefore making the approach more gorgeous from the perspective of risk diversification (Massey, 1989).

However, another significant element of migrant networks is that it enhances communication between migrants and their families in their homeland. The networks transmit information with social norms and, they can exercise control over individual behaviors to ensure the unity between the migrant host nation and his homeland. This might be especially the situation in the Nigerian society which is or possibly structured by well-demonstrated values of solidarity. In this view, the continuation of interpersonal relationships established with family members or other ethnic groups can be a constant reminder for migrants of their commitment to family ties at home. A specific outcome is that migrants should remain firmly connected with their homeland, which leads migrants to transfers money or goods to those remain, for fear of being criticized. And given the myriad of services that networks can provide them, exclusion and fear of being left without support can be an effective punishment for different people for preventing them from violating their remittance obligations.

Yang (2008) characterizes human relocation as the development of individuals starting with one spot then onto the next on the planet to build up changeless or semi-lasting living arrangement, for the most part over a political fringe.

\section{Empirical Review}

Migration is now a universal phenomenon, the World Bank (2019) says that 3 percent of total populace living temporarily or permanently outside their home country. Yang (2008) defines migration as the movement of individuals from one spot to another for the purpose of establishing stable or temporary residence, generally over the political border. Individuals can decide to move or be compelled to move. Everett Lee proposed a global migration theory in $1966 . \mathrm{He}$ explains the root cause of migration as a mixture of push and pulls factors, pressure factors that inspire individuals to leave their homeland and pull factors, which are attractive forces to people to move to new areas. The driving (push) factors include low income, a low standard of living, lowly economic prospects, threat to the life, health issues, political suppression and redundancy at homel- 
and. Attraction (pull) factors include job demand, job and good economic prospects with high incomes, political liberty, human safety, emotional welfare and a relaxed environment (Lee, 1966).

The new economy of labor migration, from hypothetical point of view, considers remittance transfers as a major aspect of a family unit dynamic strategy to decrease risk at home and increase investment opportunities in areas where credit markets, insurance and capital is preoccupied or were on unsatisfactory (Taylor, 1999). Remittances are commonly defined as the part of a migrant's income transferred from the destination of the migration to his homeland. The term generally can be seen as the transfer of money or goods, although remittances can also be sent in kind. In most literature, the term is further limited to transfers sent by migrant workers, but it is worth noting that refugees and other migrants who do not benefit from the legal status of migrant workers also send remittances (Nair, 2009). Household expenditure is one of the most significant elements in an economy. Different factors, for example, income, expenses and accessibility of merchandise and ventures, family size and the money related circumstance of families impact the conduct of family unit spending. A rising pattern in spending behavior stimulates the development of nations, while downward pattern results to stagnation. Household spending is funded by the earnings among its individuals. Income from any source is fundamental for households; therefore, remittances represents as extra income of households can have a pivotal character in the spending behavior of the beneficiary homes (Clement, 2011).

Several empirical studies found conflicting results on the effect of remittances on family expenditure. Demurger and Wang (2016) examine the inward and outside impacts of remittances on household spending in Tajikistan. They discovered that external remittances have a positive effect on the level of household consumption and a negative effect on household spending on investments, families assign internal remittances mainly to consumption and less to education and family businesses. The study revealed that remittances are not being utilized in a productive manner. Parinduri and Thangavelu (2008) in an investigation on the influence of remittances and consumption and saving pattern of migrant families in Indonesia using coincidence estimators of differences matching. The results revealed that remittances changed family utilization plans. Nevertheless, the study found no solid proof that demonstrated remittances improved the wellbeing of these families. Additionally, remittance families did not have sound education or health care, which submits that remittances may not play an important role in accelerating economic development through these two sources. In any case, the result showed that remittance families have managed to invest part of their income in traditional forms of investment, such as properties and gold jewelries. Taylor and Mora (2006) ascertain the internal and external impact of remittance on household spending in Mexico and they discovered that compared to families without migrants, families with external migrants have higher marginal investment expenditure. Families with local migrants assign a 
higher portion of spending on facilities, well-being and accommodation than families without migrants

Castaldo and Reilly (2007) apply the OLS estimator to evaluate the influence of remittances on household spending in Albania. The results indicate that family with external remittances designate a lower portion of total expenditure on food and more on durable goods than family without remittances. The study does not address the possible endogeneity of remittances. This means that parameter estimates on the effect of remittances on household spending can be one-sided and conflicting. Airola (2007) examined the utilization of remittances in Mexico. The information originated from a survey on Mexican household income and expenditure between 1984 and 2000. The investigation found that families who received remittances don't spent more than their family financial plan on food but spent substantial part on durable goods, healthcare and accommodation. Income from remittances has improved the well-being of families, especially for those below average incomes. Adams and Cuecuecha (2010) noted that remittances in Indonesia positively affect marginal spending on key consumer goods, food, while marginal spending on investment and asset decreases after receiving remittances. Valero-Gil (2009) concentrated his examination on remittances influence from welfare related spending in Mexico. The analysis adopted the Tobit model and the outcome presumed that remittances significantly influence welfare for those family units that lacked medical coverage.

Rivera and Gonzalez (2009) concentrated on the impact of external and internal remittances on consumption allocation and discovered that family unit with inner or external remittance spend more on education, wellbeing, durable goods and savings than to a family without remittances. The investigation doesn't address for likely endogeneity of remittances. Inability to control endogeneity may result to one-sided and conflicting evaluations. Viet (2008) ascertained the influence of external remittances on inequality and poverty in Vietnam using a fixed effects regression model. He discovered that household income and consumption in Vietnam have expanded in direct reaction to the inflow of external remittances. The study also found that disparity has increased marginally due to the inflows of external remittances to Vietnam. Meanwhile, the levels of poverty have decreased by a small percentage due to the inflows of foreign remittances to Vietnam. Hobbs and Jameson (2012) evaluated the influence of remittances on inequality and poverty in Nicaragua. The study found that remittances from migrants led to an increase in the number of families in Nicaragua who fall into the category of average incomes. Migration remittances from Costa Rica increased households' per capita consumption for the poor group.

\section{Research Methods}

The research methodology described the purpose of data collection and the 
techniques used in data analysis to meet the objectives of the study (Kothari, 2004). The research design adopted for this study is survey method. The researcher applies this design to investigate international migrant remittance and household expenditure pattern in Nigeria. However, Lagos Metropolis was chosen for illustration to demonstrate on the phenomenon. This design is adopted because it focused on gathering opinions and views of the respondents on the research problem and it also allows the researcher to choose a fraction of the study population. The population for this study includes all remittance receiving households in Lagos State. The target population of the study comprised of only migrant households in Lagos Metropolis, Nigeria. The sample is made up of 200 heads of households who have received remittances for three to five years before the study.

Lagos state is topographically located in the southwestern piece of Nigeria and is separated into 5 managerial zones. These zones are additionally separated into the 20 Local Government Areas. Lagos state remains the littlest in region of Nigeria's 36 states. Lagos State is apparently the most monetarily significant part of the nation, containing the country's biggest urban zone. It is a significant economic focus and would be the fifth biggest economy in Africa, in the event that it was a nation. It has the most elevated populace density of states in Nigeria. The Lagos State Government evaluates the number of inhabitants in Lagos at 17.5 million as at December 2006 (Lagos Bureau of Statistics, 2012). Being urban zone, larger part of the occupants are government workers and private representatives, with additionally other income creating jobs like fitting, hair-dressing, printing and so on can likewise be found in the territory. The greater part of its occupants is from Yoruba clan.

The study employed convenient sampling method and simple random sampling. Convenient sampling method was employed to conveniently select 5 selected wards in the study area. The simple random sampling method will be used to select 100 participants from selected wards in the study area because of its fairness and objectivity, since everyone in the population has the same chance of being selected. Questionnaire was used as the main of research instrument in this work. The questions were designed to address the questions raised in the research problems, provide data used in testing the hypothesis formulated as well as achieve the objectives of the study. The nature of the questionnaire is structured, open ended and close ended where options were given to respondents to choose from. Also they were also expected to express their opinion where options were not provided. The quantitative information acquired was assessed with the aid of S.P.S.S measurable Package. Descriptive techniques were applied and were in form of simple frequency distribution. Chi-square was similarly used to test the hypotheses.

\section{Model Specification}

The main purpose of this study is to examine migrants' remittance and economic growth in Nigeria. In specifying the model for this study, the following alpha- 
bets were used to denote the respective variables.

$$
X=f(y)
$$

where;

$$
\begin{aligned}
& x=\text { dependent variable } \\
& y=\text { independent variable } \\
& \text { And, } \\
& X=\text { Remittance } \\
& x_{1}=\text { Remittance (Rem) } \\
& Y=\text { Expenditure patterns } \\
& y_{1}=\text { Income (INC) } \\
& y_{2}=\text { Consumption (CON) } \\
& y_{3}=\text { Investment (INV) }
\end{aligned}
$$

\section{Functional Relationship}

$$
\mathrm{REM}=f(\mathrm{INC}, \mathrm{CON}, \mathrm{INV}) \cdots \mu
$$

\section{Universe Model}

$$
\begin{gathered}
Y\left(y_{1}+y_{2}+y_{3}+y_{4}\right)=f\left(x_{1}\right) \\
Y(\mathrm{INC}, \mathrm{CON}, \mathrm{INV})=f(\mathrm{REM}) \\
Y=\alpha_{0}+\alpha_{1} \mathrm{INC}+\alpha_{2} \mathrm{CON}+\alpha_{3} \mathrm{CON} \ldots *
\end{gathered}
$$

\section{Apriori Expectation}

It is expected that remittance will have positive relationship on economic growth

$\begin{array}{ll}\text { Coefficient } & \text { Expected signs } \\ \beta_{1} & \text { Positive } \\ \beta_{2} & \text { Positive } \\ \beta_{3} & \text { Positive } \\ \beta_{4} & \text { Positive }\end{array}$

Therefore, $\beta_{1} \beta_{2} \beta_{3} \beta_{4}>0$

\section{Empirical Data and Analysis}

This section focuses on the analysis and interpretation of data used to examine migrants' remittance and expenditure pattern of households in Nigeria. The findings from this study would enable the researcher in achieving the study's objectives and arriving at a suitable conclusion. The data were analyzed using Statistical Packages for Social Science (IBM SPSS) version 23. 200 questionnaires were administered while 166 were returned. Giving a response rate of $83 \%$, and this is considered reasonable to make adequate judgment on this study.

Table 1 demonstrated Socio-Demographic characteristics of respondents, it shows that $16.9 \%$ were between the age limit of 18 - 30 years, $25.3 \%$ were between the age of 31 - 40 years and $57.8 \%$ were between the age of 41 years and above. On gender distribution, 53\% were male and $47 \%$ were female. Both genders have therefore been adequately represented in the study. Moreover, on 
Table 1. Socio-demographic characteristics of respondents.

\begin{tabular}{|c|c|c|}
\hline Variable & Frequency & Percentage \\
\hline \multicolumn{3}{|l|}{ Age } \\
\hline $18-30$ years & 28 & 16.9 \\
\hline $31-40$ years & 42 & 25.3 \\
\hline 41years and above & 96 & 57.8 \\
\hline Total & 166 & 100 \\
\hline \multicolumn{3}{|l|}{ Gender } \\
\hline Male & 88 & 53.0 \\
\hline Female & 78 & 47.0 \\
\hline Total & 166 & 100 \\
\hline \multicolumn{3}{|c|}{ Total number of members in household } \\
\hline 1 - 2 members & 20 & 12.0 \\
\hline 3 - 4 members & 58 & 34.9 \\
\hline 5 members and above & 88 & 53.1 \\
\hline Total & 166 & 100 \\
\hline \multicolumn{3}{|l|}{ Household economic status } \\
\hline Poor & 50 & 30.1 \\
\hline Average & 94 & 56.6 \\
\hline Rich & 22 & 13.3 \\
\hline Total & 166 & 100 \\
\hline \multicolumn{3}{|l|}{ Household size } \\
\hline Big/Large & 80 & 48.2 \\
\hline Average & 60 & 36.1 \\
\hline Small & 26 & 15.7 \\
\hline Total & 166 & 100 \\
\hline \multicolumn{3}{|c|}{ Respondents highest level of education } \\
\hline Primary Education & 30 & 18.1 \\
\hline Secondary Education & 88 & 53.0 \\
\hline Tertiary Education & 48 & 28.9 \\
\hline Total & 166 & 100 \\
\hline \multicolumn{3}{|c|}{ Description of current employment status } \\
\hline Own business & 66 & 39.7 \\
\hline Employed & 36 & 21.7 \\
\hline Retired & 30 & 18.1 \\
\hline Unemployed & 34 & 20.5 \\
\hline Total & 166 & 100 \\
\hline
\end{tabular}

Source: Field survey: 2020.

the total number of member in households, $12.0 \%$ have $1-2$ members, $34.9 \%$ are with 3 - 4 members and $53.1 \%$ stressed on 5 members and above. On household economic status, $30.1 \%$ of the respondents were from poor homes, $56.6 \%$ were average economic status and $13.3 \%$ were from rich families. Regarding household size of respondents, $48.2 \%$ stressed on Big/Large households, $36.1 \%$ were Average households and $15.7 \%$ emphasized on Small households. On highest educational attainment of respondents, $18.1 \%$ obtained primary education, $53.0 \%$ obtained secondary education and $28.9 \%$ obtained tertiary educa- 
tion. On description of current employment status of respondents, 39.7\% owned business, $21.7 \%$ were employed, $18.1 \%$ were retirees and $20.5 \%$ were unemployed.

Table 2 revealed remittance characteristics of respondents, it affirmed that all the respondents (100\%) supported that member of households' lives away from home. On duration of migrant in abroad, $26.5 \%$ emphasized that their member spent 1 - 5 years, $53.0 \%$ stressed on 6 - 10 years and $20.5 \%$ confirmed 11 years and above. On the main reasons for members' migration, 9.6\% emphasized on

Table 2. Remittance characteristics.

\begin{tabular}{|c|c|c|}
\hline Variable & Frequency & Percentage \\
\hline \multicolumn{3}{|c|}{ Member of household lives away from home } \\
\hline Yes & 166 & 100 \\
\hline No & 0 & 0 \\
\hline Total & 166 & 100 \\
\hline \multicolumn{3}{|l|}{ Duration of migrant in abroad } \\
\hline $1-5$ years & 44 & 26.5 \\
\hline $6-10$ years & 88 & 53.0 \\
\hline 11 years and above & 34 & 20.5 \\
\hline Total & 166 & 100 \\
\hline \multicolumn{3}{|l|}{ Main reason for member migration } \\
\hline Political reasons & 16 & 9.6 \\
\hline Economic reasons & 88 & 53.0 \\
\hline Religious reasons & 24 & 14.5 \\
\hline Others & 38 & 22.9 \\
\hline Total & 166 & 100 \\
\hline \multicolumn{3}{|l|}{ Relationship with migrant } \\
\hline Wife/husband & 28 & 16.9 \\
\hline Son/daughter & 44 & 26.5 \\
\hline Father/mother & 46 & 27.7 \\
\hline Brother/sister & 28 & 16.9 \\
\hline Other & 20 & 12.0 \\
\hline Total & 166 & 100 \\
\hline \multicolumn{3}{|l|}{ Type of remittance received } \\
\hline Cash remittance & 90 & 54.2 \\
\hline Non cash remittance & 24 & 14.5 \\
\hline Cash and non-cash remittance & 52 & 31.3 \\
\hline Total & 166 & 100 \\
\hline \multicolumn{3}{|c|}{ Total value of remittance received in the 12 months } \\
\hline Less than $\# 50,000$ & 42 & 25.3 \\
\hline$\# 50,000$ - 99,999 & 46 & 27.7 \\
\hline$\# 100,000$ and above & 78 & 47.0 \\
\hline Total & 166 & 100 \\
\hline \multicolumn{3}{|c|}{ Channel through which remittances are received } \\
\hline Western union/Money gram & 56 & 33.7 \\
\hline Direct to bank transfer & 80 & 48.3 \\
\hline Friends/Returnees & 20 & 12.0 \\
\hline Postal money order & 10 & 6.0 \\
\hline
\end{tabular}




\section{Continued}

\begin{tabular}{ccc}
\hline Total & 166 & 100 \\
Frequency of remittance inflow & & \\
Monthly & 20 & 12.0 \\
Quarterly & 42 & 25.3 \\
Annually & 46 & 27.7 \\
Nonspecific period & 36 & 21.7 \\
Other & 22 & 13.3 \\
Total & 166 & 100 \\
& & \\
Remittance utilization & & 13.3 \\
Investment & 22 & 20.5 \\
Asset accumulation & 34 & 25.3 \\
Household income & 42 & 28.9 \\
Household expenditure & 48 & 12.0 \\
Other & 20 & 100 \\
Total & 166 &
\end{tabular}

Source: Field survey: 2020 .

political reasons, $53.0 \%$ stressed on economic reasons, $14.5 \%$ supported religious reasons and $22.9 \%$ confirmed on others reasons. On respondents' relationship with migrant, $16.9 \%$ affirmed wife /husband, $26.5 \%$ emphasized on son/daughter, $27.7 \%$ confirmed father/mother, $16.9 \%$ stressed on brother/sister and $12.0 \%$ stated other relationships. On type of remittance received, $54.2 \%$ of the respondents confirmed cash remittance, $14.5 \%$ confirmed non cash remittance and $31.3 \%$ received cash and non-cash remittance. On total value of remittance received in the 12 months, $25.3 \%$ of the respondents received Less than \#50,000, 27.7\% confirmed \#50,000 - 99,999 and 47.0\% affirmed \#100,000 and above. Regarding the Channel through which remittances are received, $33.7 \%$ of the respondents supported Western union/MoneyGram, 48.3\% stressed on Direct to bank transfer, $12.0 \%$ emphasized on Friends/Returnees and $6.0 \%$ supported Postal money order. On frequency of remittance inflow, $12.0 \%$ of the respondents received remittance monthly, $25.3 \%$ emphasized on quarterly, $27.7 \%$ affirmed annually, $21.7 \%$ stressed on nonspecific period and $13.3 \%$ confirmed others such as during festive periods, wedding etc. On Remittance utilization, $13.3 \%$ of the respondents invested part of the remittance, $20.5 \%$ stressed on asset accumulation, 25.3\% confirmed Household income, $28.9 \%$ emphasized on Household expenditure and $12.0 \%$ stated other use.

Table 3 shows income information of respondents. On Monthly income, it affirmed that $27.7 \%$ received less than $\# 30,000,26.5 \%$ received \#30,000 - \#39,999, $24.1 \%$ received \#40,000 - \#49,999 and 21.7\% received \#50,000 and above. Also, $36.1 \%$ of the respondents' main source of income is Salary, $16.9 \%$ emphasized on Remittances, $19.3 \%$ stressed on Business, 15.7\% supported Pension and $12.0 \%$ stated other means of income. On area of expenditure income mostly covered, $49.4 \%$ of the respondents emphasized on non-food items, $36.1 \%$ stressed on food items and $14.5 \%$ states other areas. However, $37.3 \%$ of 
Table 3. Household income.

\begin{tabular}{|c|c|c|}
\hline Variable & Frequency & Percentage \\
\hline \multicolumn{3}{|l|}{ Monthly income } \\
\hline Less than $\# 30,000$ & 46 & 27.7 \\
\hline$\# 30,000$ - \#39,999 & 44 & 26.5 \\
\hline$\# 40,000$ - \#49,999 & 40 & 24.1 \\
\hline$\# 50,000$ and above & 36 & 21.7 \\
\hline Total & 166 & 100 \\
\hline \multicolumn{3}{|c|}{ The main source of income } \\
\hline Salary & 60 & 36.1 \\
\hline Remittances & 28 & 16.9 \\
\hline Business & 32 & 19.3 \\
\hline Pension & 26 & 15.7 \\
\hline Other & 20 & 12.0 \\
\hline Total & 166 & 100 \\
\hline \multicolumn{3}{|c|}{ Area of expenditure income mostly covered } \\
\hline Non-food items & 82 & 49.4 \\
\hline Food items & 60 & 36.1 \\
\hline Others & 24 & 14.5 \\
\hline Total & 166 & 100 \\
\hline \multicolumn{3}{|c|}{ Income capacity to satisfy non-food items } \\
\hline Yes & 62 & 37.3 \\
\hline No & 104 & 62.7 \\
\hline Total & 166 & 100 \\
\hline \multicolumn{3}{|c|}{ Income capable of providing food items } \\
\hline Yes & 100 & 60.2 \\
\hline No & 66 & 39.8 \\
\hline Total & 166 & 100 \\
\hline \multicolumn{3}{|c|}{ Received remittance represents a significant } \\
\hline Yes & 134 & 80.7 \\
\hline No & 32 & 19.3 \\
\hline Total & 166 & 100 \\
\hline
\end{tabular}

Source: Field survey: 2020.

the respondents confirmed their income is capable to satisfy non-food items while $62.7 \%$ were in contrary view. Moreover, $60.2 \%$ of the respondents emphasized their income is capable to satisfy food items and $39.8 \%$ were in opposite view. Meanwhile, $80.7 \%$ of the respondents supported that Received remittance represents a significant percentage of household income while $19.3 \%$ were in opposite view.

Table 4 revealed the expenditure pattern of participants. On average monthly expenditure on food items, $25.3 \%$ of the respondents spent less than \#30,000, $38.6 \%$ spent $\# 30,000$ - 40,999 and $36.1 \%$ spent \#50,000 and above. On average monthly expenditure on health service, $38.6 \%$ of the respondents spent less than $\# 30,000,33.7 \%$ spent \#30,000 - 40,999 and spent 27.7\% \#50,000 and above. On average monthly expenditure on housing, $43.4 \%$ of the respondents spent less 
Table 4. Households expenditure pattern.

\begin{tabular}{|c|c|c|}
\hline Variable & Frequency & Percentage \\
\hline \multicolumn{3}{|c|}{ Average monthly expenditure on food items } \\
\hline Less than \#30,000 & 42 & 25.3 \\
\hline$\# 30,000$ - 40,999 & 64 & 38.6 \\
\hline$\# 50,000$ and above & 60 & 36.1 \\
\hline Total & 166 & 100 \\
\hline \multicolumn{3}{|c|}{ Average monthly expenditure on health service } \\
\hline Less than $\# 30,000$ & 64 & 38.6 \\
\hline$\# 30,000-40,999$ & 56 & 33.7 \\
\hline$\# 50,000$ and above & 46 & 27.7 \\
\hline Total & 166 & 100 \\
\hline \multicolumn{3}{|c|}{ Average monthly expenditure on housing } \\
\hline Less than \#30,000 & 72 & 43.4 \\
\hline$\# 30,000$ - 40,999 & 62 & 37.3 \\
\hline$\# 50,000$ and above & 32 & 19.3 \\
\hline Total & 166 & 100 \\
\hline \multicolumn{3}{|c|}{ Average monthly expenditure on consumer } \\
\hline \multicolumn{3}{|l|}{ and durables goods } \\
\hline Less than \#30,000 & 84 & 50.6 \\
\hline$\# 30,000-40,999$ & 52 & 31.3 \\
\hline$\# 50,000$ and above & 30 & 18.1 \\
\hline Total & 166 & 100 \\
\hline \multicolumn{3}{|c|}{ Average monthly expenditure on transportation } \\
\hline Less than \#30,000 & 88 & 53.0 \\
\hline$\# 30,000$ - 40,999 & 58 & 34.9 \\
\hline$\# 50,000$ and above & 20 & 12.0 \\
\hline Total & 166 & 100 \\
\hline \multicolumn{3}{|c|}{$\begin{array}{l}\text { Remittance received cover a substantial proportion of } \\
\text { household expenditure }\end{array}$} \\
\hline Yes & 120 & 72.3 \\
\hline No & 46 & 27.7 \\
\hline Total & 166 & 100 \\
\hline \multicolumn{3}{|c|}{ Major area of remittance expenditure mostly covered } \\
\hline Food items & 40 & 24.1 \\
\hline Health service & 24 & 14.5 \\
\hline Housing & 36 & 21.7 \\
\hline Consumer and durables goods & 22 & 13.3 \\
\hline Transportation & 20 & 12.0 \\
\hline Other & 24 & 14.4 \\
\hline Total & 166 & 100 \\
\hline \multicolumn{3}{|c|}{$\begin{array}{l}\text { The extent at which remittance inflow influences } \\
\text { consumption and expenditure of households }\end{array}$} \\
\hline To a large extent & 90 & 54.3 \\
\hline To no extent & 20 & 12.0 \\
\hline To a low extent & 56 & 33.7 \\
\hline Total & 166 & 100 \\
\hline
\end{tabular}

Source: Field survey: 2020. 
than $\# 30,000,37.3 \%$ spent \#30,000 - 40,999 and spent $19.3 \# 50,000$ and above. On average monthly expenditure on consumer and durables goods, $50.6 \%$ of the respondents spent less than $\# 30,000,31.3 \%$ spent $\# 30,000-40,999$ and $18.1 \%$ spent \#50,000 and above. On average monthly expenditure on transportation, $53.0 \%$ of the respondents spent less than $\# 30,000$ monthly, $34.9 \%$ spent $\# 30,000$ 40,999 and $12.0 \%$ spent \#50,000 and above. Regarding the major area of remittance expenditure mostly covered, $24.1 \%$ of the respondents stressed on Food items, $14.5 \%$ emphasized on Health service, $21.7 \%$ stated Housing, and $13.3 \%$ supported Consumer and durables goods, $12.0 \%$ affirmed Transportation and $14.4 \%$ emphasized on other areas. Looking at the extent at which remittance inflow influences expenditure patterns of households, $54.3 \%$ emphasized to a large extent, $12.0 \%$ stressed to no extent and $33.7 \%$ affirmed to a low extent.

Table 5 revealed the investment decisions of the respondents; it affirmed

Table 5. Investment assessments of respondents.

\begin{tabular}{|c|c|c|}
\hline Variable & Frequency & Percentage \\
\hline \multicolumn{3}{|c|}{ Investment decisions of respondents on remittance inflow } \\
\hline Yes & 98 & 59.0 \\
\hline No & 68 & 41.0 \\
\hline Total & 83 & 100 \\
\hline \multicolumn{3}{|c|}{ Main factor that prevent respondents from investment } \\
\hline Legal constraints & 8 & 11.8 \\
\hline Corruption & 10 & 14.7 \\
\hline Trust issues & 14 & 20.6 \\
\hline Income constraints & 16 & 23.5 \\
\hline High tax rates & 12 & 17.6 \\
\hline Other & 8 & 11.8 \\
\hline Total & 68 & 100 \\
\hline \multicolumn{3}{|c|}{ Main area of remittance investment } \\
\hline Agriculture & 22 & 22.4 \\
\hline Real estate & 12 & 12.2 \\
\hline Oil and gas & 10 & 10.2 \\
\hline Education & 20 & 20.4 \\
\hline Trading & 34 & 34.6 \\
\hline Total & 98 & 100 \\
\hline \multicolumn{3}{|c|}{ Total amount of profit made monthly on investment } \\
\hline Less than $\# 50,000$ & 22 & 22.4 \\
\hline$\# 50,000$ - 99,999 & 46 & 46.9 \\
\hline$\# 100,000$ and above & 30 & 39.7 \\
\hline Total & 98 & 100 \\
\hline \multicolumn{3}{|c|}{$\begin{array}{c}\text { The extent at which investment contributed to } \\
\text { household livelihood }\end{array}$} \\
\hline To a large extent & 48 & 48.9 \\
\hline To no extent & 14 & 14.3 \\
\hline To a low extent & 36 & 36.8 \\
\hline Total & 98 & 100 \\
\hline
\end{tabular}

Source: Field survey: 2020. 
$59.0 \%$ of the respondents emphasized that they invested part of the remittance received while $41.0 \%$ used it non-investment purposes. On the Main factor that prevent respondent from investing part of remittance, $11.8 \%$ stressed Legal constraints, $14.7 \%$ stated Corruption, $20.6 \%$ had Trust issues, $23.5 \%$ emphasized Income constraints, $17.6 \%$ indicated High tax rates and $11.8 \%$ stressed on other factors. On main area of remittance investment, 22.4\% indicated Agriculture, 12.2\% stressed on Real estate, $10.2 \%$ affirmed Oil and gas, $20.4 \%$ stated Education and $34.6 \%$ emphasized on Trading. On total amount of profit made monthly on investment, $22.4 \%$ earned less than \#50,000, 46.9\% earned \#50,000 99,999 and 39.7\% earned \#100,000 and above. Regarding the extent at which investment contributed to household livelihood, $48.9 \%$ emphasized on a large extent, $14.3 \%$ stressed on no extent and $36.8 \%$ affirmed to a low extent.

\section{Test of Research Hypotheses}

This section centers around testing the hypotheses expressed for the investigation. The Chi-square indicators was utilized in testing if there were statistical significance in respondents' opinion towards each of the three hypotheses expressed for investigation.. The tests and discoveries are summed up beneath.

Decision rule: The decision standard was to dismiss the null hypothesis, if the $p \leq 0.05$ i.e. reject $\mathrm{H}_{0}$ if the $\mathrm{p}$ value is lower than or equal to 0.05 , or else accept.

The degree of importance is 0.05 .

\section{Hypothesis I}

Ho: There is no significant relationship between migrant remittances and households income level in Nigeria.

Hi: There is a significant relationship between migrant remittances and households income level in Nigeria.

Table 6 and Table 7 revealed the first hypothesis result for the study. This first table shows a cross tabulation between the two variables used to test the hypothesis while the second table represents the chi-square test statistics. The Pearson chi-square value is $293.433^{\mathrm{a}}$ with a significant of 0.000 . Since the $p$-value of 0.000 is less than 0.05; the null hypothesis is rejected and the alternative accepted, implying that there is a significant relationship between migrant remittances and income level of households in Nigeria.

Table 6. Migrant remittances and income level of households Crosstabulation: test count.

\begin{tabular}{|c|c|c|c|c|c|}
\hline & & \multicolumn{3}{|c|}{ Remittance inflow within a year } & \multirow[b]{2}{*}{ Tota } \\
\hline & & $\begin{array}{c}\text { Less than } \\
\# 50,000\end{array}$ & $\# 50,000$ - 99,999 & $\begin{array}{l}\# 100,000 \\
\text { and above }\end{array}$ & \\
\hline \multirow{4}{*}{ Monthly income } & Less than $\# 30,000$ & 42 & 4 & 0 & 46 \\
\hline & $\# 30,000$ - \#39,999 & 0 & 42 & 2 & 44 \\
\hline & $\# 40,000$ - \#49,999 & 0 & 0 & 40 & 40 \\
\hline & $\# 50,000$ and above & 0 & 0 & 36 & 36 \\
\hline \multicolumn{2}{|r|}{ Total } & 42 & 46 & 78 & 166 \\
\hline
\end{tabular}


Table 7. Migrant remittances and income level of households Crosstabulation: chi-square tests.

\begin{tabular}{cccc}
\hline & Value & $\mathrm{df}$ & Asymp. Sig. (2-sided) \\
\hline Pearson Chi-Square & $293.433^{\mathrm{a}}$ & 6 & 0.000 \\
Likelihood Ratio & 307.882 & 6 & 0.000 \\
Linear-by-Linear Association & 140.836 & 1 & 0.000 \\
N of Valid Cases & 166 & &
\end{tabular}

${ }^{\mathrm{a}} 0$ cells $(0.0 \%)$ have expected count less than 5 . The minimum expected count is 9.11 .

\section{Hypothesis II}

Ho: There is no significant relationship between migrant remittances and spending pattern of households in Nigeria.

Hi: There is a significant relationship between migrant remittances and spending pattern of households in Nigeria.

Table 8 and Table 9 revealed the second hypothesis result for the study. This first table shows a cross tabulation between the two variables used to test the hypothesis while the second table represents the chi-square test statistics. The Pearson chi-square value is $272.243^{\mathrm{a}}$ with a significant of 0.000 . Since the $p$-value of 0.000 is less than 0.05 ; the null hypothesis is rejected and the alternative accepted, implying that there is a significant relationship between migrant remittances and spending pattern of households in Nigeria.

\section{Hypothesis III}

Ho: There is no significant relationship between migrant remittances and investment decisions of households in Nigeria.

Hi: There is a significant relationship between migrant remittances and investment decisions of households in Nigeria.

Table 10 and Table 11 revealed the second hypothesis result for the study. This first table shows a cross tabulation between the two variables used to test the hypothesis while the second table represents the chi-square test statistics. The Pearson chi-square value is $129.951^{\mathrm{a}}$ with a significant of 0.000 . Since the $p$-value of 0.000 is less than 0.05 ; the null hypothesis is rejected and the alternative accepted, implying that there is a significant relationship between migrant remittances and investment decisions of households in Nigeria.

\section{Discussion of Findings}

The study examined migrants' remittance and expenditure pattern of households in Nigeria. In the course of this study, three hypotheses were tested. The result of the first hypothesis revealed that there is a significant relationship between remittance and income level of households. This result is consistent with the results of Peter and Valkenburg (2008) which showed that remittance revenues are accumulated for households belonging to the lower ladder of income distribution, aiding recipient households to climb the income scale. They claimed that income from remittances has a positive and significant effect on children's 
Table 8. Migrant remittances and expenditure pattern of households Crosstabulation: test count.

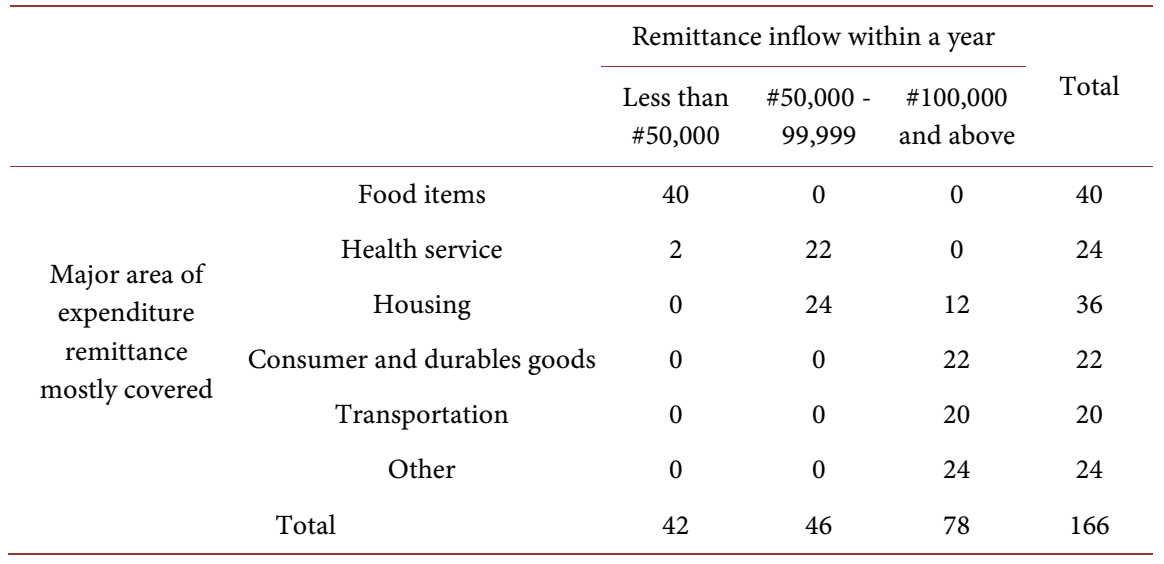

Table 9. Migrant remittances and expenditure pattern of households Crosstabulation: chi-square tests.

\begin{tabular}{cccc}
\hline & Value & df & Asymp. Sig. (2-sided) \\
\hline Pearson Chi-Square & $272.243^{\mathrm{a}}$ & 10 & 0.000 \\
Likelihood Ratio & 291.737 & 10 & 0.000 \\
Linear-by-Linear Association & 129.979 & 1 & 0.000 \\
N of Valid Cases & 166 & & \\
\hline
\end{tabular}

${ }^{\mathrm{a}} 0$ cells $(0.0 \%)$ have expected count less than 5 . The minimum expected count is 5.06 .

Table 10. Migrant remittances and investment decisions of households Crosstabulation: test count.

\begin{tabular}{cccccc}
\hline & & \multicolumn{3}{c}{ Remittance inflow within a year } & \\
\cline { 3 - 5 } & & $\begin{array}{c}\text { Less than } \\
\# 50,000\end{array}$ & $\# 50,000-99,999$ & $\begin{array}{c}\# 100,000 \\
\text { and above }\end{array}$ & Total \\
\cline { 3 - 5 } Investment decisions & Yes & 42 & 46 & 10 & 98 \\
Total & No & 0 & 0 & 68 & 68 \\
\hline
\end{tabular}

Table 11. Migrant remittances and investment decisions of households Crosstabulation: chi-square tests.

\begin{tabular}{cccc}
\hline & Value & df & Asymp. Sig. (2-sided) \\
\hline Pearson Chi-Square & $129.951^{\mathrm{a}}$ & 2 & 0.000 \\
Likelihood Ratio & 164.931 & 2 & 0.000 \\
Linear-by-Linear Association & 103.892 & 1 & 0.000 \\
N of Valid Cases & 166 & & \\
\hline
\end{tabular}

${ }^{a} 0$ cells $(0.0 \%)$ have expected count less than 5 . The minimum expected count is 17.20.

health and education, but not on apparent consumption or accumulation of assets, while remittances help to increase family income in migrant sending areas. 
The result of the second hypothesis emphasized that there is a significant relationship between remittance and consumption expenditure of households. The results obtained were supported by a study by Olowa and Awoyemi (2012) which found that remittances affect household spending in rural Nigeria. However, they concluded that families who receive remittances spend less on the consumption of food, consumer goods and durable goods than families who do not receive remittances.

On the third hypothesis, the result of the findings indicated that there is a significant relationship between remittance and investment decisions of households. Similar results were observed by Singh et al. (2011) discovered that remittances act as a backup and nations with well-working bodies and foundations seem to profit most from the capability of remittances. He concluded that remittances support investments during recessions and serve as reserves in beneficiary countries.

\section{Conclusion and Recommendations}

Migration plays a significant role in developing nations and it is essential to see how beneficiary households use them. The inquiry on what remittances signify to households is still a subject of discussion. The manner in which remittances are utilized on income, consumption or investment is strictly evaluated by the context of the analysis. A few nations can encourage beneficial utilization of remittances better than others. The study examines migrants' remittance and expenditure pattern of households in Nigeria. In order to explore the relationship between worker remittances and household expenditure pattern, Chi-square statistical analysis is utilized. From the findings of the study, it can therefore be deduced that there is a significant relationship between remittance and household income in Nigeria. Similarly, a positive relationship has been found with remittance inflow and consumption expenditure of households in Nigeria. Also, the study established that remittance significantly influences investment decisions of households in Nigeria.

Remittances in developing nations are frequently viewed as one of the fundamental sources of external financing. Nigeria is no special case. Over past decades, the inflow of remittances from Nigerian migrants has expanded fundamentally. Aside from positive macroeconomic impacts on financial development and advancement, the remittance impacts family units on the small scale level, raising their income and, therefore, changing consumption and investment patterns. Remittances represent a consistent and changeless progression of money related assets for those family units that are intensely reliant on such income source and can be consequently be seen as permanent income. In this case, families can make consumption and investment decisions based on them. Remittance beneficiary households will in general spend more on consumption and investment in human development in general, which implies that the income from remittances seems to allow for sustained consumption. From this study, it is 
clear that families have also used remittances for social purposes, such as weddings, funerals and ceremonies. Migrants support the social functions of their families, because they consider it an investment and therefore expect similar help in the future.

In the realm of the above deductions, the below recommendations are made:

1) The government should improve the collection and monitoring of data on remittances and migratory flows and related financial information to manage them better, as this would promote research that will lead to a better understanding of migration decisions, remittance spending patterns and its influence on investment of households.

2) Policy makers should create useful policies to encourage the use of remittances to support long-term development and income security. Policies should aim to encourage migrants to channel remittances through official channels rather than through informal channels and this will also help them to keep their savings in the form of financial assets rather than abroad.

3) The government should conduct enlightenment campaigns to raise awareness of the benefits of using remittances for investment rather than consumption that will enable migrant workers to transfer more funds and support investments in their homelands.

\section{Conflicts of Interest}

The author declares no conflicts of interest regarding the publication of this paper.

\section{References}

Adams, R. H. (2011). Remittances, Investment and Rural Asset Accumulation in Nigeria. Economic Development and Cultural Change, 47, 155-173. https://doi.org/10.1086/452390

Adams, R. H., \& Cuecuecha, A. (2010). The Economic Impact of International Remittances on Poverty and Household Consumption and Investment in Indonesia. Washington DC: World Bank. https://doi.org/10.1596/1813-9450-5433

Airola, J. (2007). The Use of Remittance Income in Mexico. International Migration Review, 41, 850-859. https://doi.org/10.1111/j.1747-7379.2007.00111.x

Amanda, B. (2020). The Impact of COVID-19 on Remittances for Development in Africa. 2020 Discussion Paper No. 269. http://ecdpm.org/dp269

Anyanwu, J. C., \& Erhijakpor, A. E. (2010). Do International Remittances Affect Poverty in Africa? African Development Review, 22, 51-91. https://doi.org/10.1111/j.1467-8268.2009.00228.x

Arango, J. (2000). Explaining Migration: A Critical View. International Social Science Journal, 52, 283-296. https://doi.org/10.1111/1468-2451.00259

Bozorgmehr, M., \& Sabagh, G. (1990). A Comparison of Exiles and Immigrants: Iranians in Los Angeles. Leiden.

Castaldo, A., \& Reilly, B. (2007). Do Migrant Remittances Affect the Consumption Patterns of Albanian Households? South-Eastern Europe Journal of Economics, 1, 25-54. 
Clement, M. (2011). Remittances and Household Expenditure Patterns in Tajikistan: A Propensity Score Matching Analysis. Asian Development Review, 28, 58-87. https://doi.org/10.2139/ssrn.2001145

Demurger, S., \& Wang, X. (2016). Remittances and Expenditure Patterns of the Left Behinds in Rural China. IZA Discussion Paper No. 9640. https://doi.org/10.1016/j.chieco.2015.12.002

Doeringer, P. B., \& Piore, M. J. (1971). Internal Labor Markets and Manpower Analysis. Lexington, MA: Heath Lexington Books.

Hobbs, A. W., \& Jameson, K. P. (2012). Measuring the Effect of Bi-Directional Migration Remittances on Poverty and Inequality in Nicaragua. Applied Economics, 44, 2451-2460. https://doi.org/10.1080/00036846.2011.564153

Kothari, F. J. (2004). Survey Research Methods (3rd ed.). Thousand Oaks, CA: Sage.

Kyaing, K. T. (2012). Pull and Push Factors of Migration: A Case Study in the Urban Area of Monywa Township, Myanmar.

https://www.worldofstatistics.org/files/2014/03/Pull-and-Push-Factors-of-Migration-T het.pdf

Lagos Bureau of Statistics (2012). Population by Sex and Local Government area in Lagos State: 2006.

https://nairametrics.com/wp-content/uploads/2013/03/Lagos-State-LGA-Statistics-201 2.pdf

Lee, E. S. (1966). A Theory of Migration. Demography, 3, 47-57. https://doi.org/10.2307/2060063

Massey, D. S. (1988). Economic Development and International Migration in Comparative Perspective. Population and Development Review, 14, 383-413. https://doi.org/10.2307/1972195

Massey, D. S. (1989). Social Structure, Household Strategies, and the Cumulative Causation of Migration. The Annual Meeting of the American Sociological Association, San Francisco, 13 August 1989.

Massey, D. S., Alarcón, R., Durand, J., \& González, H. (1987). Return to Aztlan: The Social Process of International Migration from Western Mexico. Oakland, CA: University of California Press.

Massey, D. S., Arango, J., Hugo, G., Kouaouci, A., Pellegrino, A., \& Taylor, J. E. (1993). Theories of International Migration: A Review and Appraisal. Population and Development Review, 19, 431-466. https://doi.org/10.2307/2938462

Nair, R. P. (2009). The Impacts of Gender and Remittance on Household's Expenditure Pattern in Nepal. Unpublished Graduate Thesis, Washington DC: Graduate School of Arts and Science.

OECD (2017). A Profile of Immigrant Populations in the 21st Century: Data from OECD Countries. Paris: OECD Publishing.

Olowa, O., \& Awoyemi, T. (2012). Determinants of Migration and Remittances in Rural Nigeria. Journal of Development and Agricultural Economics, 4.

Parinduri, R. A., \& Thangavelu, S. M. (2008). Remittance and Migrant Households' Consumption and Saving Patterns: Evidence from Indonesia. Nottingham University Business School Malaysia Campus Research Paper No. 2008-02.

https://doi.org/10.2139/ssrn.1146366

Piore, M. J. (1969). On-the-Job Training in the Dual Labor Market: Public and Private Responsibilities in on The-Job Training of Disadvantaged Workers. In A. R. Weber, F. H. Cassell, \& W. L. Ginsburg (Eds.), Public-Private Manpower Policies. Madison, WI 
Industrial Relations Research Association.

Piore, M. J. (1970). Jobs and Training. In The State and the Poor. Cambridge, MA: Winthrop.

Piore, M. J. (1975). Notes for a Theory of Labor Market Stratification. In Labor Market Segmentation (pp. 125-150). Lexington, MA: DC Heath.

Rivera, M., \& Gonzalez, A. (2009). Effects of Remittances on Household Expenditure Patterns of Rural Mexico. New Haven, CT: Hewlett Foundation, The Macmillan Center, Yale University.

Singh, R. J., Haacher, M., Lee, K., \& Le, G. M. (2011). Determinants and Macro-Economic Impact of Remittances in Sub-Saharan Africa. Journal of African Economy, 20, 312-340. https://doi.org/10.1093/jae/ejq039

Stark, O., \& Lucas, R. E. (1985). Motivations to Remit: Evidence from Botswana. Journal of Political Economy, 93, 901-917. https://doi.org/10.1086/261341

Stark, O., \& Lucas, R. E. (1988). Migration, Remittances, and the Family. Economic Development and Cultural Change, 36, 465-481. https://doi.org/10.1086/451670

Taylor, E. (1999). The New Economics of Labor Migration and the Role of Remittance in the Migration Process. International Migration Quarterly Review, 37, 63-88. https://doi.org/10.1111/1468-2435.00066

Taylor, J. E., \& Mora, J. (2006). Does Migration Reshape Expenditures in Rural Households? Evidence from Mexico. Policy Research Working Paper Series 3842, Washington DC: The World Bank. https://doi.org/10.1596/1813-9450-3842

Valero-Gil, J. N. (2009). Remittances and the Household's Expenditures on Health. Journal of Business Strategies, 26, 119-126.

Viet, C. N. (2008). Do Foreign Remittances Matter to Poverty and Inequality? Evidence from Vietnam. Economic Bulletin, 15, 1-11.

Waheed, O. O., Timothy, A. T., Adebayo, S. M., \& Ayodele, O. (2013). Effects of Remittances on Poverty among Rural Households in Nigeria. European Journal of Sustainable Development, 2, 263-284. https://doi.org/10.14207/ejsd.2013.v2n4p263

World Bank (2015). World Development Report. Washington DC: World Bank.

World Bank (2018). Global Economic Prospect 2018: Economic Implications of Remittances and Migration. Washington DC: The World Bank.

World Bank (2019). Remittance Prices Worldwide. Washington DC: World Bank.

World Bank (2020). Remittances Data in Brief. Washington DC: The World Bank.

Yang, D. (2008). International Migration, Remittances, and Household Investment: Evidence from Philippine Migrants' Exchange Rate Shocks. The Economic Journal, 118, 591-630. https://doi.org/10.1111/j.1468-0297.2008.02134.x 